International Scientific Organization

http://iscientific.org/

Chemistry International

www.bosaljournals.com/chemint/

\title{
Genotoxicity and carcinogenicity of traditionally roasted meat using indicator polycyclic aromatic hydrocarbons (PAHs), Port Harcourt, Nigeria
}

\author{
Fidelity Mene Deeduah and Godson Ndubuisi Iwuoha*
}

\begin{abstract}
Department of Pure and Industrial Chemistry, Faculty of Science, University of Port Harcourt, Choba, Nigeria
*Corresponding author's E. mail: holygodson@yahoo.com
\end{abstract}

\section{A R T I C L E I N F O}

\section{Article type:}

Research article

Article history:

Received March 2021

Accepted May 2021

July 2021 Issue

Keywords:

Genotoxicity

Carcinogenicity

Polycyclic aromatic hydrocarbons

Toxicity equivalent factor

GC-FID

\section{A B S T R A C T}

This research is targeted to employ indicator like PAHs, mainly PAH4 and PAH8 to evaluate the genotoxicity and carcinogenicity of PAHs in traditionally roasted meat (Suya) in selected locations at Port Harcourt metropolis, Nigeria, since its estimation using toxicity equivalent factor (TEF) model is not convenient. Suya sample were obtained at designated locations in the metropolitan city and were analyzed for PAHs present in them by using GC-FID and Chemstation after the PAHs were extracted using USEPA 8270 method. The series of results clearly indicated that indicator PAHs, i.e., PAH4 gave the best outlook on genotoxicity and carcinogenicity potential of the Suya over PAH8, PAH2 and Bap indicator PAHs and also visibly showed peak loadings of $0.15131 \mu \mathrm{g} / \mathrm{Kg}$, which indicates that the sample Suya meat is not genotoxic or carcinogenic especially when correlated with current maximum regulatory value of $12 \mu \mathrm{g} / \mathrm{Kg}$ for PAH4. Regular consumption of Suya is however risky and may expose consumers to cancer.

(C) 2021 International Scientific Organization: All rights reserved.

Capsule Summary: Improved roasting methods revealed relatively lower PAHs values with PAH4 indicator, PAHs reflecting the best genotoxic and carcinogenic risk potential of the Suya meat samples.

Cite This Article As: D. F. Mene and G. N. Iwuoha. Genotoxicity and carcinogenicity of traditionally roasted meat using indicator polycyclic aromatic hydrocarbons (PAHs), Port Harcourt, Nigeria. Chemistry International 7(3) (2021) 217-223.

https://doi.org/10.5281/zenodo.4900600

\section{INTRODUCTION}

large class of organic compounds that contains two or more fused aromatic rings made up of carbon and hydrogen atoms. PAHs are primarily formed by burning or pyrolysis or incomplete combustion of organic materials, like food, waste, and other anthropogenic activities. Humans are exposed to PAHs through many pathways like tobacco smoking, food, breathing etc. Studies have shown that PAHs are toxic to humans and the toxicological effects are countless; haematotoxicity, immunotoxicity, reproductive and developmental defects and causing death. A vast array of
PAHs especially benzo(a)pyrene (BaP) has been shown to be carcinogenic to experimental animals and humans, hence PAHs presence in food stuffs rings alarming bell to environmentalists. PAHs, like polychlorinated biphenyl (PCBs) and dioxin are lipophilic compounds and thus do not persist for long time in human body. (IARC, 2012).

In the past decades, toxicological data on PAHs were evaluated by the scientific committee on food (SCF), International programme on chemical safety (IPSC) and joint FAO/WHO experts committee on food additives (JECFA). The SCF committee concluded that 15 PAHs namely benz (a) anthracene, benzo (b) fluoranthene benzo (j) fluoranthene, benzo $(\mathrm{k})$ fluoranthene, benzo $(\mathrm{g}, \mathrm{h}, \mathrm{i})$ perylene, benzo (a) 
pyrene, chrysene, cyclopenta (cd) pyrene, dibenzo (a,h) anthracene, debenzo $(\mathrm{a}, \mathrm{e})$ pryrene, debenzo $(\mathrm{a}, \mathrm{h})$ pyrene, dibenzo $(\mathrm{a}, \mathrm{i})$ pyrene, dibenzo $(\mathrm{a}, \mathrm{l})$ pyrene, indeno $(1,2,3-\mathrm{cd})$ pyrene and 5-methylchrysene show clear evidence of mutagenicity/genotoxicity in somatic cell in experimental animals in vivo. With the exception of benzo(ghi)perylene, have also indicated clear carcinogenic effects in experimental animals. The SCF recommended that all 15 of these compounds should be regarded as potentially genotoxic and carcinogenic to humans and therefore, there is the risk of long-term adverse health effects following dietary intake of PAHs (FAO/WHO, 2005)

Following the reviews by SCF, 2005/108/EC, JECFA (2005), EFSA (2008) and EFSA's CONTAM panel (2008), the panel concluded that for PAHs in food, Toxic equivalent factor (TEF) approach is not valid because of lack of data from oral carcinogenicity studies on individuals PAHs, their different mode of action and the evidence of poor predictivity of carcinogenic potency of PAH mixtures based on the current proposed TEF values. Therefore the CONTAM panel concluded that based on Culp et al. (1998) studies on oral carcinogenicity data following measures from two coal tar mixtures analysis, that benzo (a) pyrene, benz (a) anthracene, benzo (b) fluoranthene, benzo $(\mathrm{k})$ fluoranthene, benzo (ghi) perylene, chrysene, dibenz $(\mathrm{a}, \mathrm{h})$ anthracene and Indeno (1,2,3-cd) pyrene were the most suitable indicators either individually or in a combination, are currently the only possible indicators of the carcinogenic potency of PAHs in food. Overall, the panel concluded that PAH4 (Sum of benzo (a) pyrene, benz (a) anthracene, benzo (b) fluoranthene and chrysene and PAH8 (the sum of PAH4, benzo (4) fluoranthene, benzo (ghi) perylene, debenz $(\mathrm{a}, \mathrm{h})$ anthracene and indeno $(1,2,3-\mathrm{cd})$ pyrene) were the most suitable indicators for occurrence and toxicity of PAHs in food, with PAH8 not providing much added value compared to PAH4. Following above findings, separate maximum limits were updated legislatively now for benzo (a) pyrene and PAH4. EFSA (2005a).

Recent studies by Ekaye et al. (2019), Akpoghelie (2012) and Owor et al. (2012) on the loadings of PAHs in barbecued chicken and grilled Suya, Suya meat and roasted pork meat respectively indicates very alarming PAHs level in the respective meat samples above the respective maximum recommended values.

The aim of this research is to assess the loading of PAHs in traditionally roasted cow meat popularly called Suya in selected parts of Port Harcourt metropolis. The resulting data will be used to determine the extent of toxicity of genotoxic and carcinogenic PAHs in the Suya using the various indicator PAHs (BaP, PAH2, PAH4, and PAH8) for $\mathrm{PAH}$ occurrence and toxicity in traditionally roasted and smoked Cow meat. Special focus here is given to PAH4, PAH8 and BaP PAHs indicators because PAH4 and PAH8 are the most suitable indicators of PAHs in food with PAH8 not providing much added value compared to PAH4. The BaP indicator is in view here to ascertain its suitability or otherwise as it was not recommended by experts. The final outcome will be informative enough to appropriate authorities.

\section{MATERIAL AND METHODS}

\section{Study area}

The study area comprises of five sample locations. Sample location 1: The first Suya meat samples were bought at Igbogo road near the junctions going into Rumuchera Choba in Obio/Akpor Local Government Area of Rivers State. Sample location 2: The second suya meat samples were bought at Rumuchera (Okocha Town Hall) junction Choba in Obio/Akpor Local Government Area of Rivers State. Sample location 3: The third meat samples were bought at Rumuchera opposite Dufil Prima Foods Factory (Indomie) gate at Choba in Obio/Akpor Government Area of Rivers State. Sample location 4: The fourth sample of meats was bought at Seven Day Adventist junction Owhipa Choba ObioAkpor Local Government Area of Rivers State. The loin of the cow meat was bought from suya meat seller which was butchered at Choba slaughter. Sample location 5. The fifth meat samples were bought at chocolate lounge suya stand Owhipa Choba Port Harcourt Obio/Akpor Local Government Area of Rivers State.

\section{Sampling}

A total of five (5) samples from five (5) sampling points were collected on the $27^{\text {th }}$ of May, 2019 as the sampling details. The samples were sorted, preserved as per standard requirement/procedures and the parameters requested for were noted. The details were documented in the chain of custody form and the samples were transferred to the laboratory, stored in the freezer to maintain the sample integrity prior to analysis. All the samples were analyzed at Geospectra Engineering Services and Consultants limited Port Harcourt.

\section{Principle, apparatus and reagent}

A measured volume of sample was extracted with a mixture of 1,1 dichloromethane and acetone. The extract is then concentrated and analyzed by GC/FID (Gas Chromatography/Flame ionization Detector). Gas chromatography equipped with chemistry work station, capillary column and flame lionization detector, Rotary evaporator, Filter paper, Separatory funnel, $10 \mathrm{ml}$ syringe, measuring cylinder, $100 \mathrm{ml}$ volumetric flask, $100 \mathrm{ml}$ clear and dry conical flask, Burette state, Analytical balance, Dry clean vials for storing of extract $(2 \mathrm{ml})$. PAHs primary standards (accu standard), HPLC grade dichloromethane, acetone, anhydrous sodium sulphate $\left(\mathrm{Na}_{2} \mathrm{SO}_{4}\right)$ and chromic acid.

\section{Extraction procedure}



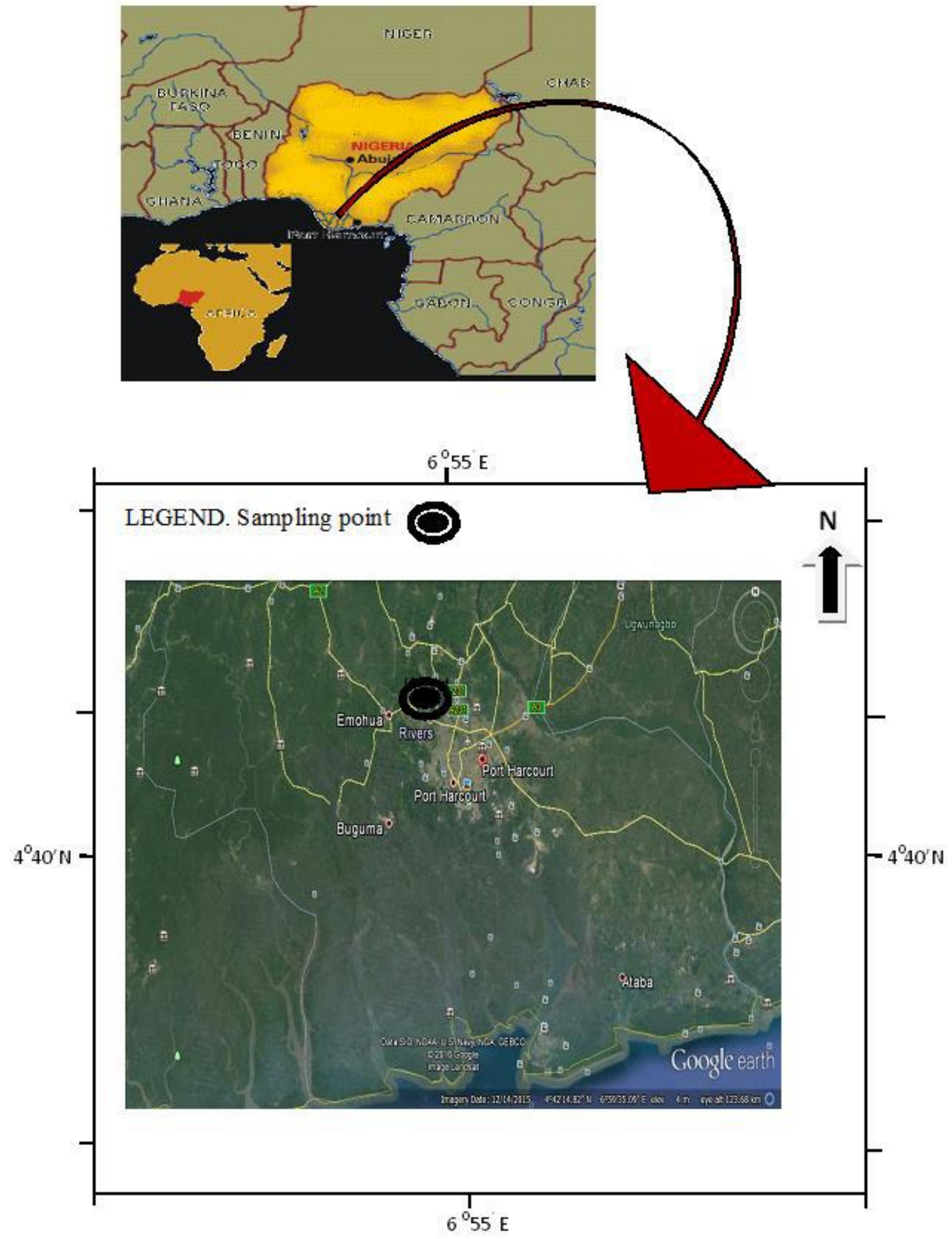

Fig. 1: Map of Port Harcourt, Nigeria indicating sampling point (Rumuodumaya) Google Earth (2020) 
Table 1: PAHs concentrations $(\mu \mathrm{g} / \mathrm{kg})$ in Suya meat samples of cow at various sites at Port Harcourt metropolis

\begin{tabular}{|c|c|c|c|c|c|}
\hline PAHs & $\begin{array}{c}\text { IGBOGO } \\
\text { road }\end{array}$ & $\begin{array}{c}\text { Rumuchera } \\
\text { junction }\end{array}$ & Indomie gate & SDA junction & Chocolate hotel \\
\hline Naphthalene & - & 0.00169 & - & - & - \\
\hline $\begin{array}{l}\text { 2-Methyl } \\
\text { Naphthalene }\end{array}$ & - & 0.00132 & - & - & - \\
\hline $\begin{array}{l}\text { Naphthalene } \\
\text { Acenaphthene }\end{array}$ & 0.00238 & 0.00318 & 0.00191 & 0.00178 & 0.00225 \\
\hline Acenaphthylene & 0.00180 & 0.00196 & 0.00189 & 0.00190 & 0.00171 \\
\hline Fluorene & 0.00181 & 0.00198 & 0.00186 & 0.00182 & 0.00185 \\
\hline Phenanthrene & 0.00495 & 0.00744 & 0.00386 & 0.00399 & 0.00433 \\
\hline Anthracene & 0.00203 & 0.00201 & 0.00173 & 0.00787 & 0.00188 \\
\hline Fluoranthene & 0.00207 & 0.00242 & 0.00205 & 0.00273 & 0.00360 \\
\hline Pyrene & 0.00278 & 0.00309 & 0.00295 & 0.00397 & 0.00509 \\
\hline Chrysene & 0.01601 & 0.00410 & 0.00260 & 0.00623 & 0.00554 \\
\hline $\begin{array}{l}\text { Benz (a) } \\
\text { Anthracene }\end{array}$ & 0.03015 & 0.00621 & 0.00185 & 0.00784 & 0.00283 \\
\hline $\begin{array}{l}\text { Benzo (b) } \\
\text { Fluoranthene }\end{array}$ & 0.02812 & 0.04546 & 0.02808 & 0.12929 & 0.04624 \\
\hline $\begin{array}{l}\text { Benzo (k) } \\
\text { Fluoranthene }\end{array}$ & 0.00435 & 0.00825 & 0.02120 & 0.01932 & 0.03480 \\
\hline $\begin{array}{l}\text { Benzo (a) Pyrene } \\
\text { Dibenz (a,h) } \\
\text { Anthracene }\end{array}$ & $\begin{array}{c}0.00550 \\
-\end{array}$ & 0.00866 & 0.01158 & 0.01033 & $\begin{array}{c}0.01470 \\
-\end{array}$ \\
\hline $\begin{array}{l}\text { Benzo }(g, h, i) \\
\text { perylene }\end{array}$ & - & - & - & - & - \\
\hline $\begin{array}{l}\text { Indeno }(1,2,3-c d) \\
\text { pyrene }\end{array}$ & - & - & - & - & - \\
\hline
\end{tabular}

Table 2: Maximum regulatory values (MRV) for BaP and PAH4 and PAHs indicators concentrations $(\mu \mathrm{g} / \mathrm{kg}$ ) in Suya meat samples of cow at various sites at Port Harcourt metropolis

\begin{tabular}{|c|c|c|c|c|c|c|}
\hline PAHs & $\begin{array}{l}\text { MRV } \\
2014\end{array}$ & $\begin{array}{c}\text { IGBOGO } \\
\text { road }\end{array}$ & $\begin{array}{l}\text { Rumuchera } \\
\text { junction }\end{array}$ & Indomie gate & SDA junction & Chocolate hote \\
\hline Bap & $5(30)$ & 0.00550 & 0.00866 & 0.01158 & 0.01033 & 0.01470 \\
\hline РАH2 & Not indicated & 0.02151 & 0.01276 & 0.01418 & 0.01656 & 0.02024 \\
\hline PAH4 & $2,(12)$ & 0.07978 & 0.06443 & 0.04411 & 0.15131 & 0.06931 \\
\hline PAH8 & Not indicated & 0.08413 & 0.07268 & 0.06531 & 0.27063 & 0.10411 \\
\hline
\end{tabular}

Five grams of well mixed wet sample was weighed into an acid washed and acetous rinsed beaker. A $30 \mathrm{ml}$ of 1,1 dichloromethane was added and sonicated for $30 \mathrm{~min}$. The solvent phase was carefully passed through a filter paper containing $3 \mathrm{~g}$ of anhydrous sodium sulphate and preconditioned with dischloromethane and acetone. The second $20 \mathrm{ml}$ of 1.1 dischloromethane and acetone was added into the beaker and carefully extracted through a filter paper. It was later concentrated into $3 \mathrm{ml}$ using rotary evaporator. It was thereafter fractionated for aromatic using column chromatography packed with glass wool and silica gel.

US EPA 8270 method was employed for the extraction of polyaromatic hydrocation (PAHs) from five Suya meat samples. A $5 \mathrm{~g}$ of homogenized sample was quantitatively measured using $100 \mathrm{ml}$ beaker $30 \mathrm{ml} \mathrm{1,1}$ dichloromethane and acetone were added to the sample inside the beaker. The sample was thereafter shaken using a mechanical shaker for 30 mins. The solvent layer was allowed to settle for 5 minutes and was recovered into extract vial. The Suya samples were re-extracted with $20 \mathrm{ml}$ of the dischloromethane. The combined extract was dried by passing it through a funnel containing the anhydrous sodium sulphate. The sample was fractionated and concentrated using a rotary evaporator and the extract was taken with a vial bottle.

\section{PAHs analysis using GC-FID}

The gas chromatography (GC-FID) was calibrated using hydrocarbon standards containing 17 components of PAHs manufactured by ACUU standard, USA. The extract was then analyzed for gas chromatography analysis using GC-FID for 
17 PAHs compound. Then $1 \mu \mathrm{l}$ of elutes from each of the Suya samples was injected into the GC/FID for quantification of polycyclic aromatic hydrocarbons (PAHs). Agilent Chemstation software was then used for data processing of the analyzed samples.

\section{RESULTS AND DISCUSSION}

Twelve PAHs were detected above the detection limit namely, Acenaphthylene, Acenaphthene, Flourene, Phnanthrene, Anthranthene, Flourenthene, Pyrene, Chrysene, Benz(a) anthracene, Benzo (b) flouranthene,
Benzo (k) flouranthene and Benzo(a) Pyrene. Their various concentrations $(\mu \mathrm{g} / \mathrm{kg})$ vary from site to site and individually within a site. In addition to above named detected PAHs at all sites, Naphthalene and 2methylanaphthalene were also detected in the suya from Rumuchera Junction. Dibenz (a,h) anthracene, Benzo (g, h) Perylene, Indeno (1,2,3-cd) pyrene were below detection limit in the various Suya at all sites (Table 1-2). In comparison, the concentration of individual PAHs recorded in this research is quite significantly lower than that obtained by other researchers like Ekaye et al. (2019) who obtained concentration $(\mu \mathrm{g} / \mathrm{kg}$ ) levels of 529.92 and 1710.8

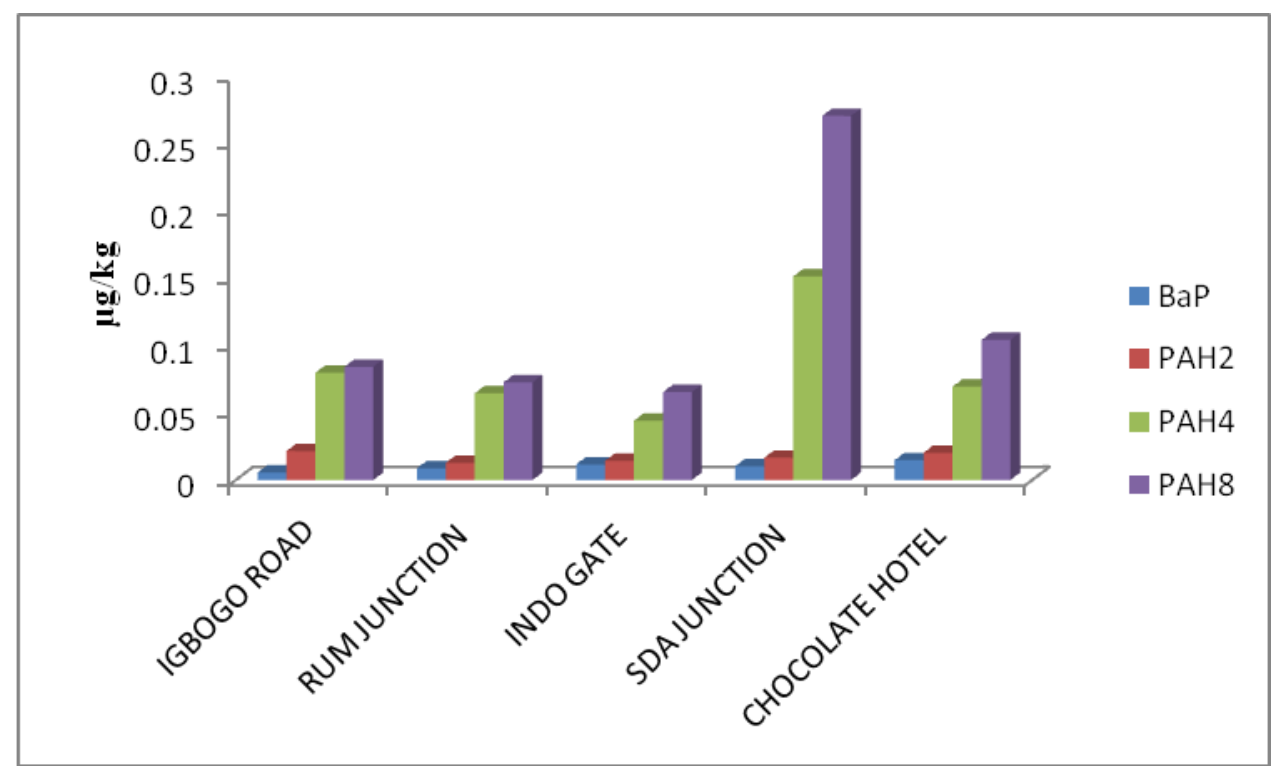

Fig. 2: Loadings of various indicator PAHs at different sites

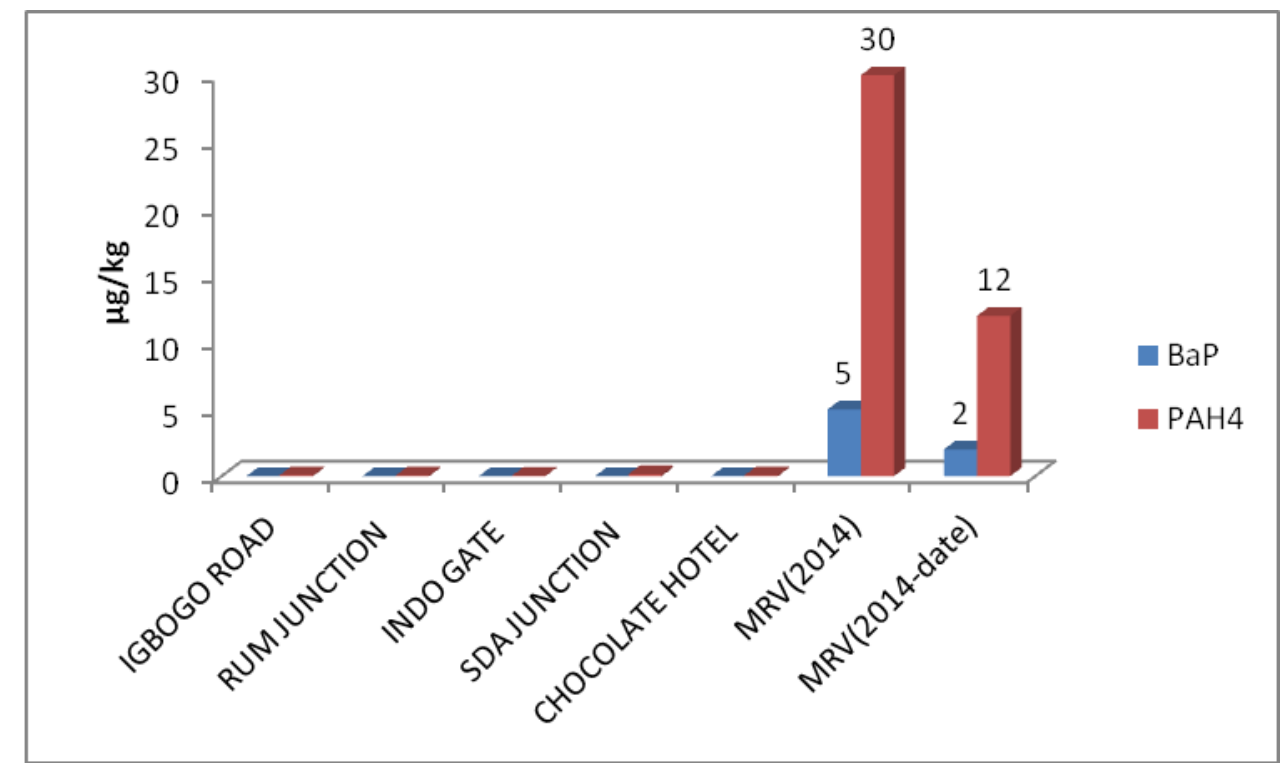

Fig. 3: Loads of indicator PAHs (BaP, PAH4) at different sites and maximum regulatory values (MRV) 
for Indeno (1,2,3-cd) pyrene and Dibenz (a,h) anthracene respectively in commonly consumed barbecued chicken and grilled Suya meat. Akpoghelie (2012) similarly obtained higher values of PAHs in Suya meat in Warri, Nigeria. The lower PAHs concentration loadings obtained in this research comparatively could be attributed to improved methods of roasting meat (Suya) in Port Harcourt metropolis targeted to minimize Suya contaminated with PAHs.

Figure 2 shows the Bap as an indicator PAHs gradually increased in the Cow Suya samples from Igbogo to Rumuchera junction to Indomie gate to SDA junction to Chocolate hotel with respective loading $(\mu \mathrm{g} / \mathrm{kg})$ of 0.00550 , $0.00866,0.01158,0.01033$ and 0.01470 . Its loading from the various Suya site s ranged from 0.00550 to 0.01470 $\mu \mathrm{g} / \mathrm{kg}$. In analysis of PAH2 as an indicator PAHs, the PAH2 loading $(\mu \mathrm{g} / \mathrm{kg})$ in the Suya from Igbogo Road, Rumuchera Junction, Indomie gate, SDA Junction, Chocolate hotel locations are respectively $0.02151,0.01276,0.01418$, 0.01656 and 0.02024 . Its loading $(\mu \mathrm{g} / \mathrm{kg}$ ) from the various Suya sites ranged from 0.01276 to $0.02151(\mu \mathrm{g} / \mathrm{kg})$.

The loading and variation of PAH4 as an indicator PAHs across the Suya samples from the five sites is presented in Figure 2. The concentrations $(\mu \mathrm{g} / \mathrm{kg})$ are $0.07978,0.06443,0.04411,0.15131$ and 0.06931 respectively for Igbogo Road, Rumuchera Junction, Indomie gate, SDA Junction and Chocolate hotel sites. Its loading from the various Suya sites ranged from 0.04411 to $0.15131(\mu \mathrm{g} / \mathrm{kg})$.

For PAH8 as PAHs indicator, load was detected to be $0.08413,0.07268,0.06531,0.27063$ and 0.10411 $(\mu \mathrm{g} / \mathrm{kg})$, respectively for Igbogo Road, Rumuchera Junction, Indomie gate, SDA junction and Chocolate hotel sample sites, respectively (Fig. 2). Its loading $(\mu \mathrm{g} / \mathrm{kg})$ from the various Suya sites ranged from 0.06531 to $0.27063(\mu \mathrm{g} / \mathrm{kg}$ ). The SDA Junction Suya accounted for the peak loading of PAH4 $(0.15131 \mu \mathrm{g} / \mathrm{kg})$ and PAH8 $(0.27063 \mu \mathrm{g} / \mathrm{kg})$ indicators PAHs while Igbogo Road and Chocolate hotel Suya samples respectively accounted for $\mathrm{PAH} 2$ and Bap indicator PAHs peak loading of 0.02151 and 0.01470 $(\mu \mathrm{g} / \mathrm{kg})$, respectively. It can be observed that PAH4 and PAH8 charts are stand-out indicator PAHs providing similar trends of analysis and with PAH8 not providing anything much more significant that PAH4 indicator PAH, has not already provided.

The comparison of the level of simplest indicator PAHs, i.e., Bap and the best indicator PAHs (Fig. 3), i.e., PAH4 across the Suya sites with their respective maximum regulation values MRV before 2014 and after 2014 till date. This clearly show that Suya sample are not yet genotoxic or carcinogenic to consumers. Again, the indicator PAHs results here for Bap and PAH4 are significantly lower than Owor et al (2012) observations for Bap and PAH4 in roasted pork meat in two locations of his study, which are 3.11 and $3.32(\mu \mathrm{g} / \mathrm{kg})$ for $\mathrm{BaP}$ and 17.16 and $19.49(\mu \mathrm{g} / \mathrm{kg})$ for PAH4.

\section{CONCLUSIONS}

The presence and formation of PAHs in food especially meat is of serious concern and this research has further demonstrated that Bap assessment analysis alone cannot be a better way of knowing the genotoxic or carcinogenic potential of Cow Suya meat products. Application of Indicator PAHs (PAH4 and PAH8) are better ways of knowing the genotoxic and carcinogenic potentials of traditionally roasted meat sample and from our estimation in the research traditionally roasted meat (Suya) are relatively safer, not genotoxic or carcinogenic for once in a while consumer. This could be attributed to improved meat roasting methods. Frequent consumption of Cow Suya might increase the genotoxic and carcinogenic risk of PAHs in traditionally roasted meat.

\section{REFERENCES}

Akpoghelie, 0.J., 2018. Assessment of Polycyclic Aromatic Hydrocarbons (PAHs) on Smoked Fish and Suya Meat Consumed in Warri, Nigeria. Journal of Chemical Society of Nigeria 43, 422-431.

Agency for Toxic Substances and Disease Registry (ATSDR), 1995. Toxicological profile for polycyclic aromatic hydrocarbons. U.S. Department of Health and Human Services, Public Health Service, Agency for Toxic Substances and Disease Registry. http://www.atsdr.cdc.gov/toxprofiles/tp69.pdf.

Culp, S.J., Gaylor, D.W., Sheldon, W.G., Goldstein, L.S., Beland, F.A., 1998. A comparison of the tumours induced by coal tar and benzo[a]pyrene in a 2-year bioassay. Carcinogenesis 19, 117-124.

European Commission (EC), 2001. Outcome of the expert group meeting on 3 October on ways to prevent contamination of olive residue oil and other oils with polycyclic aromatic hydrocarbons (PAH). http://europa.eu.int/comm/food/fs/rc/scfs/rap09_en.p df

European Commission (EC), 2002. Opinion of the Scientific Committee on Food on the risks to human health of Polycyclic Aromatic Hydrocarbons in food. http://ec.europa.eu/food/fs/sc/scf/out153_en.pdf

European Food Safety Authority (EFSA), 2005a. Opinion of the Scientific Committee on a request from EFSA related to a harmonized approach for risk assessment of substances which are both genotoxic and carcinogenic. The EFSA Journal 282, 1-31. http://www.efsa.europa.eu/EFSA/Scientific_Opinion/sc_ op_ej282_gentox_en3,0.pdf

European Food Safety Authority (EFSA) 2009. Polycyclic Aromatic Hydrocarbons in Food, Scientific Opinion of the EFSA Panel on Contaminants in the Food Chain. ttp://www.efsa.europa.eu/cs/BlobServer/Scientific_Opi nion/contam_ej_724_PAHs_en,1.pdf?ssbinary=true

Ekaye, S.O, Erhunmwunse, N.O. Asemota C.0., 2019. Levels of PAHs in commonly consumed barbecued chicken and 
grilled meat suya in Benin metropolis. Society for Experimental Biology of Nigeria Journal 19, 117.

Food and Agriculture Organization of the United Nations/World Health Organization. (FAO/WHO), 2005. Joint FAO/WHO Expert Committee on Food Additives (JECFA). Sixtyfourth meeting, Rome, 8-17 http://www.who.int/ipcs/food/jecfa/summaries/summ ary_report_64_final.pdf

Food and Agriculture Organization of the United Nations/World Health Organization (FAO/WHO), 2006. Safety evaluation of certain contaminants in food. Prepared by the Sixty-fourth meeting of the Joint FAO/WHO Expert Committee on Food Additives (JECFA). International Agency for Research on Cancer (IARC), 2012. IARC Monographs 92, 100F Available at: http://monographs.iarc.fr/ENG/Monographs/vol100F/ mono100F-14.pdf

Joint FAO/WHO Expert Committee on Food Additives (JECFA), 2005. Sixty-fourth meeting. Rome, 8-17. Summary and conclusions. JECFA/64/SC. Available at: http://www.who.int/ipcs/food/jecfa/summaries/summ ary_report_64_final.pdf

Owor, O.R., Nyakairu G.W.A., Mbabazi, J., Kwetegyeka, J., 2012. PAHs in roasted pork, kampala, Uganda. International Journal of Current Research 4, 42-48.

Scientific Committee on Food (SCF), 2002. Opinion of the Scientific Committee on Food on the risks to human health of Polycyclic Aromatic Hydrocarbons in Food SCF/CS/CNTM/PAH/29Final. Available at: http://ec.europa.eu/food/fs/sc/scf/out153_en.pdf

European Food Safety Authority, 2008. Polycyclic aromatic hydrocarbons in food-scientific opinion of the panel on contaminants in the food chain. EFSA Journal 6, 724.

World Health Organization/The International Agency for Research on Cancer (WHO/IARC), 1986. Tobacco Smoking. IARC Monographs on the Evaluation of Carcinogenic Risks to Humans 38. International Agency for Research on Cancer, Lyon.

World Health Organization/The International Agency for Research on Cancer (WHO/IARC), 1989. Occupational exposures in petroleum refining: Crude oil and major petroleum fuels.

IARC, 1987. Monographtson the evaluation of the carcinogenic risk of chemicals to humans. Lyon, France: IARC.

World Health Organization (WHO), 1998. International Programme on chemical safety. Environmental health criteria 202. Selected non-heterocyclic polycyclic aromatic hydrocarbons. Available at: http://www.inchem.org/documents/ehc/ehc/ehc202.ht $\mathrm{m}$

World Health Organization/International Programme on Chemical Safety (WHO/IPCS), 1998. Selected Nonheterocyclic Polycyclic Aromatic Hydrocarbons. Environmental Health Criteria 202. International Programme on Chemical Safety, World Health Organization, Geneva.
World Health Organization (WHO), 2006. Food and Agriculture Organization of the United Nations FAO. http://whqlibdoc.who.int/publications/2006/92416605 54_eng.pdf

World Health Organization/International Programme on Chemical Safety (WHO/IPCS), 2007. Draft guidance document on characterizing and communicating uncertainty in exposure. Assessment. http://www.who.int/ipcs/methods/harmonization/area s/draftundertainty.pdf

Visit us at: http://bosaljournals.com/chemint/ Submissions are accepted at: editorci@bosaljournals.com 